\title{
PRIMERJAVA PLANSKEGA IN DEJANSKEGA STANJA V PROSTORU OBČINE MEDVODE
}

\author{
Janez Berdavs \\ Univerza na Primorskem, Znanstveno-raziskovalno središče \\ Garibaldijeva I, SI-6000 Koper/Capodistria \\ e-mail: janez.berdavs@zrs.upr.si
}

Strokovni članek

COBISS 1.04

\begin{abstract}
Izvleček
Članek želi na primeru prostora občine Medvode oceniti uspešnost planskega sistema, ki je bil vzpostavljen leta 1984 in ki se izteka šele v današnjem času. Članek primerja načrtovano stanje v prostoru občine glede na dolgoročni in družbeni plan iz leta 1986 z dejanskim stanjem ob sprejetju novega Zakona o urejanju prostora leta 2003. Analiza razlogov za nizko stopnjo izvedenosti plana kaže, da razlogi niso le $\mathrm{v}$ neupoštevanju predpisov, ampak tudi $\mathrm{v}$ samem sistemu prostorskih predpisov.
\end{abstract}

Ključne besede: občina, Medvode, prostorsko planiranje, prostorska zakonodaja

\section{A COMPARISON OF PLANNED AND ACTUAL SITUATION IN SPACE OF THE MEDVODE MUNICIPALITY}

\begin{abstract}
The article assesses effectiveness of spatial planning system in Slovenia on the case of the Medvode municipality. The planned state in space, according to the plan from 1986, is compared with actual state in the year 2003, when the new planning law was adopted. Low level of system effectiveness is not only the consequence of disregard of spatial legislation, but also of systemic deficiencies within the system of spatial legislation.
\end{abstract}

Key words: municipality, Medvode, spatial planning, spatial legislation 


\section{UVOD}

V tem članku je predstavljeno vrednotenje uspešnosti sistema prostorskega načrtovanja v Sloveniji na primeru občine Medvode. V času izoblikovanja novega planskega sistema, katerega mejnik je sprejetje Zakona o prostorskem načrtovanju aprila 2007, je analiza in ovrednotenje starega planskega sistema še kako aktualna tema. Ker reforma planskega sistema, zastavljena s sprejemom Zakona o urejanju prostora leta 2003 ni nikoli popolnoma zaživela, je smiselno vrednotiti predhodni planski sistem, vzpostavljen z Zakonom o sistemu družbenega planiranja in o Družbenem planu SR Slovenije, sprejetim januarja 1980 (Uradni list SRS 1/80, Uradni list SRS 33/80), Zakonom o urejanju prostora iz leta 1984 (Uradni list SRS 18/84, Uradni list SRS $15 / 89$ in Uradni list RS 71/93) ter Zakonom o urejanju naselij in drugih posegov v prostor, ki je bil prvič objavljen skupaj z Zakonom o urejanju prostora.

Ta sistem je za vsako od takratnih velikih občin - t.i. komun - predvideval izdelavo dolgoročnega plana, na podlagi katerega naj bi bili izdelani podrobnejši planski dokumenti. Dolgoročni plani naj bi veljali za obdobje 15 let. Večina občin je dolgoročne plane, ki so vsebovali za temo članka pomembne prostorske sestavine, sprejela za obdobje 1986-2000, veljavnost prostorskih sestavin pa je bila ob izteku podaljšana. Obdobje od sprejema dolgoročnih planov do sprejema novega Zakona o urejanju prostora leta 2003 je zato najprimernejše obdobje za analizo učinkovitosti slovenskega sistema prostorskega planiranja v novejšem času.

Metodološko temelji raziskava na primerjalni analizi planskega stanja glede na prostorske sestavine dolgoročnega plana in dejanskega stanja v prostoru občine Medvode leta 2003. Dolgoročni plan je bil v prvi fazi ovrednoten glede na načela, ki v urejanju prostora veljajo danes in ki so tudi formalizirana z Zakonom o prostorskem načrtovanju, Evropskimi prostorsko razvojnimi perspektivami, Politiko urejanja prostora RS, Strategijo prostorskega razvoja Slovenije in Prostorskim redom Slovenije. Zaželenega stanja pri primerjalni analizi ne pojmujemo kot popolno izvedenost plana iz leta 1986 v letu 2003 (po koncu planskega obdobja), saj so se v času izvajanja plana spreminjale potrebe v prostoru, družbene razmere in tudi sama planerska stroka.

Plansko stanje po dolgoročnem planu je bilo soočeno z dejanskim stanjem. Dejansko stanje je bilo ugotovljeno z ortofoto posnetki, ogledi na terenu in gradivi Občine Medvode (infrastrukturna omrežja). Pri analizi izvedenosti plana smo se osredotočili na izvedenost tistih planskih določil, ki so bila v fazi ovrednotenja prepoznana kot še vedno aktualna. Ocenjena je bila stopnja izvedenosti dolgoročnega plana v letu 2003.

Sledila je analiza razlogov za ugotovljeno stopnjo izvedenosti dolgoročnega plana, izvedena predvsem na osnovi intervjujev z vodjo Oddelka za okolje in prostor občine Medvode, g. Arturjem Olajem, in pregledom ter analizo dolgoročnemu planu podrejenih planskih aktov. Analiza je bila osredotočena na normativni vidik delovanja planskega sistema. Zanimalo nas je predvsem, kako so določila hierarhično višjih planskih aktov konkretizirana $\mathrm{v}$ aktih nižjih ravni (izvedbeni akti) in, podobno kot pri dolgoročnem planu, v kolikšni meri odražajo splošna načela urejanja prostora. V končni fazi je sledila še analiza samega izvajanja izvedbenih aktov. Vse analize dokumentov so bile opravljene po stanju aktov v letu 2003, vključno s spremembami in dopolnitvami med letoma 1986 in 2003, v analizo pa so bili vključeni tudi akti, razveljavljeni v tem obdobju. 
Analize izvedenosti planov so zapostavljeno področje v znanstveni literaturi, kljub pomembnosti tovrstnih analiz za razumevanje delovanja in za snovanje reform planskega sistema. Objav, ki bi neposredno predstavljale analize izvedenosti planov ni, kopica prispevkov pa se tematsko deloma prekriva s tem člankom: nekateri obravnavajo prostorski razvoj, drugi planski sistem. Zelo malo je bilo raziskav, ki bi v središče pozornosti postavljale pravne akte kot instrument urejanja prostora. Na tem mestu naj omenimo delo Brede Ogorelec (1991), ki se je $\mathrm{v}$ devetdesetih letih raziskovalno ukvarjala $\mathrm{z}$ normativnim urbanizmom.

Obravnavano območje obsega celotno ozemlje občine Medvode, ne glede na dejstvo, da nekateri planski akti obravnavajo precej širše območje. Občina Medvode je ena od t.i. priljubljanskih občin, nastala leta 1994 z izločitvijo iz dotedanje občine Ljubljana-Šiška. Po površini meri $78 \mathrm{~km}^{2}$ in ima 14.793 prebivalcev (2007; 2003: 14.314 preb.). Medvoška občina je zaradi svoje lege pod močnimi razvojnimi pritiski, saj se nahaja v suburbanem pa-su okoli Ljubljane, ob cestni in železniški povezavi med Ljubljano in Kranjem. Različni naravnogeografski pogoji in različna prometna povezanost posameznih delov občine povzročajo heterogenost tudi pri rabi površin, moči urbanizacijskih pritiskov in tipih urbanizacije.

Fizičnogeografsko lahko občino razdelimonajugozahodnidel,kispadak Polhograjskemu hribovju, in ravninski severovzhodni del z nekaj osamelci, ki predstavlja del Ljubljanske kotline. Občino približno po sredini seka reka Sava, v katero se v Medvodah izliva reka Sora. Ugodna prometna lega ob mostišču čez Savo in Soro, na cesti in železnici med Ljubljano in Kranjem je pogojevala razvoj Medvod v lokalno središče. Ob prisotnosti železnice je bila razpoložljivost vodne energije dejavnik zgodnje industrializacije Medvod. Intenzivna suburbanizacija v okolici Medvod in organizirana gradnja v Medvodah se kaže v hitri rasti prebivalstva od leta 1960 do danes (preglednica 1).

Preglednica 1: Gibanje števila prebivalstva občine Medvode v obdobju 1961-2007

Table 1: Population of Medvode municipality 1961-2007

\begin{tabular}{|l|l|l|l|l|l|}
\hline $\mathbf{1 9 6 1}$ & $\mathbf{1 9 7 1}$ & $\mathbf{1 9 8 1}$ & $\mathbf{1 9 9 1 *}$ & $\mathbf{2 0 0 2}$ & $\mathbf{2 0 0 7}$ \\
\hline 7835 & 9429 & 11.596 & 12.541 & 14.151 & 14.793 \\
\hline
\end{tabular}

Vira: Dalla Valle 2001; SI-STAT podatkovni portal.

* Podatki popisa 1991 preračunani na metodologijo popisa 2002.

V medvoški občini je 31 naselij; edino mestno naselje so Medvode, kjer živi tretjina prebivalstva občine. Po Vrišerjevi klasifikaciji sodijo Medvode v tretjo stopnjo središčnih naselij (Geografski atlas Slovenije 1998). Kot industrijsko in središčno naselje izkazujejo Medvode že tradicionalno največjo raznolikost urbanih rab površin. Značilen je velik delež površin za proizvodne dejavnosti; Medvode so tudi edino naselje $\mathrm{z}$ večstanovanjsko gradnjo $\mathrm{v}$ občini. Za obdobje po letu 1991 je značilen proces decentralizacije proizvodnih dejavnosti, saj je bilo v okolici zgrajenih več manjših proizvodnih obratov in tovarna filtrov v bližini obstoječe papirnice na Ladji.

Ostala, nekdaj kmečka naselja v ravninskem delu občine so močno suburbanizirana in pogosto medsebojno zraščena. Manj suburbanizirana so le naselja na robu občine, saj je sub- 
urbanizacija najprej zajela naselja v bližini središča občine, ki so prometno bolje povezana $\mathrm{z}$ Ljubljano. Tradicionalni tip naselij v ravninskem delu občine je predalpski tip gručaste vasi, ki je deloma ohranjen na severnem in vzhodnem robu občine (Geografski atlas Slovenije 1998). Temu je v določeni meri sledil tudi proces suburbanizacije, saj se je ta odvijala na robu naselij in ni ustvarjala novih poselitvenih otokov.

V Polhograjskem hribovju so naselja precej manjša. Proces suburbanizacije se je pričel bistveno kasneje kot v ravninskem delu in je zaenkrat zajel lažje dostopna naselja. Ostala naselja prebivalstveno stagnirajo. Tradicionalni tip naselij po Geografskem atlasu Slovenije (1998) so samotne kmetije, med katere pa se mešajo tudi posamezni zaselki. Tudi v tem primeru se je proces suburbanizacije usmerjal na robove obstoječih, predvsem lažje dostopnih zaselkov. Nekateri zaselki so se tako razvili v manjša gručasta ali obcestna naselja.

\section{DOLGOROČNI PLAN OBČIN IN MESTA LJUBLJANE ZA OBDOBJE 1986-2000 ZA OBMOČJE OBČINE MEDVODE}

Kot je predvideval sistem družbenega planiranja, je vseh pet ljubljanskih občin leta 1985 sprejelo Dolgoročni plan občin in mesta Ljubljane za obdobje 1986-2000 (Uradni list SRS 11/86), v nadaljevanju dolgoročni plan), ki poleg prostorskega načrtuje tudi socialni in gospodarski razvoj občin. Dejavnost prostorskega planiranja v planu nima mesta, ki bi ustrezalo njeni usklajevalni vlogi. Poleg tega je bil dolgoročni plan izdelan za območje petih ljubljanskih občin, območje današnje občine Medvode pa predstavlja le manjši del ozemlja ene od nekdanjih občin. Usmeritve dolgoročnega plana, ki se tičejo območja občine Medvode, so zato pogosto podane za celotno okolico mesta Ljubljane (današnje priljubljanske občine) ali pa za severni del okolice mesta (za razliko od manj razvitega primestnega prostora $\mathrm{v}$ takratnih občinah Ljubljana Vič-Rudnik in Ljubljana Moste-Polje).

Dolgoročni plan oz. njegove prostorske sestavine je za uresničevanje predvideval hierarhijo podrejenih planskih aktov. V planskem obdobju naj bi vsaka občina sprejela tri srednjeročne petletne družbene plane. Občina Ljubljana-Šiška je tako sprejela Družbeni plan občine Ljubljana-Šiška za obdobje 1986-1990 (Uradni list SRS 45/86). Preostala dva predvidena družbena plana zaradi spremembe družbenega sistema nista bila sprejeta. Prostorske sestavine dolgoročnega in družbenega plana naj bi bile uresničevane s prostorskimi izvedbenimi akti (PIA), bodisi z manj podrobnimi prostorskimi ureditvenimi pogoji (PUP), ali pri večjih posegih $\mathrm{v}$ prostor $\mathrm{z}$ bolj podrobnimi prostorskimi izvedbenimi načrti (PIN). Zadnji se delijo naprej na zazidalne načrte (ZN), ureditvene načrte (UN) in lokacijske načrte $(\mathrm{LN})$.

Temeljne usmeritve prostorskega razvoja po dolgoročnem planu so »smotrnejše prostorsko razporejanje dejavnosti in ustreznejša namenska raba prostora... ( (Dolgoročni plan občin in mesta Ljubljane... 1986, 850), kar naj bi se v kontekstu primestnega prostora odrazilo $\mathrm{v}$ odpiranju delovnih mest in rasti števila prebivalstva $\mathrm{v}$ primestnih območjih ter hkratni ohranitvi dnevne migracije na ravni iz sredine osemdesetih, oz. v padcu relativne dnevne migracije. Nastala naj bi policentrična aglomeracija vseh naselij in mest na območju ljubljanskih občin, sčimer bi bile kvaliteta življenja in razvojne možnosti čim bolj enakovredne na celotnem območju takratnih ljubljanskih občin. 
Poselitev naj bi v planskem obdobju usmerjali v kombinacijo koncentričnega, krakastega in policentričnega koncepta. $\mathrm{V}$ primestnih območjih naj bi zasledovali rast $\mathrm{v}$ krakih, $\mathrm{v}$ izvenmestnem območju pa naj bi poselitev - večinoma bi šlo za organizirano enodružinsko gradnjo višjih gostot - usmerili v lokalna razvojna središča.

Za usmerjanje poselitve so ključnega pomena območja urejanja oziroma ureditvena območja naselij, kot jih je določil dolgoročni plan v karti namenske rabe površin. Dolgoročni plan sledi Zakonu o urejanju prostora iz leta 1984, ki vzpostavlja načelo usmerjanja poselitve $\mathrm{v}$ ureditvena območja naselij in poudarja potrebo po usmerjanju poselitve $\mathrm{v}$ ureditvena območja tistih naselij, ki s svojimi funkcijami služijo širšim gravitacijskim območjem. Poselitev se usmerja izven ureditvenih območij naselij le, če so objekti neposredno namenjeni kmetijstvu, gozdarstvu, pridobivanju rudnin, turizmu ali rekreaciji (Zakon o urejanju naselij in drugih posegov v prostor 1984). Gradnja izven ureditvenih območij naselij je bila torej dovoljena le $\mathrm{v}$ posebnih primerih.

Na območju današnje občine Medvode sta dolgoročni in družbeni plan v 15-letnem planskem obdobju predvidevala izgradnjo kar 891 stanovanj samo v soseskah, ki bi bile zgrajene z zazidalnimi načrti. Od teh naj bi jih bilo 613 zgrajenih v večstanovanjski gradnji, 278 pa $\mathrm{v}$ enostanovanjski gradnji.

Planske usmeritve za oblikovanje naselij obsegajo upoštevanje zakonitosti in značilnosti tradicionalnih kulturno-pokrajinskih tipov in uvajanje značilne 'arhitekture mesta'. Za Polhograjsko hribovje plan predvideva ohranjanje pokrajinskega videza in varovanje pred vidnimi posegi. Novo stanovanjsko gradnjo predvideva le v redkih območjih okoli nekaterih obstoječih zaselkov, upoštevana bi morala biti tradicionalni sistem graditve in tradicionalni materiali. Za suburbano območje na savski ravnici plan predvideva največjo možno zaščito preostalih kmetijskih zemljišč.

Plan je načrtoval uvedbo učinkovitega javnega potniškega prometa, ki bi temeljil na integraciji različnih prevoznih sredstev, usklajenih voznih redih in enotni vozovnici. Sistem bi temeljil na primestni železnici v primestnih območjih in tramvaju v mestu Ljubljana. Sistem bi dopolnjevale priključne avtobusne proge, $\mathrm{P}+\mathrm{R}$ parkirišča ter kolesarnice. Individualni motorni promet bi bil le dopolnilo sistemu javnega prevoza.

Predvidena je bila gradnja nekaterih lokalnih in regionalnih cest na območju občine Medvode, gradnja drugega tira na gorenjski železniški progi zaradi nameravane uvedbe primestnega železniškega prometa ter gradnja hitre železniške proge Ljubljana-Jesenice. Na področju komunalne infrastrukture so bile glavne planske usmeritve gradnja komunalnih omrežij, skladno s stavbno gradnjo, in gradnja čistilnih naprav.

Vredno je omeniti še plansko usmeritev na področju trgovine: »Zaradi varčevanja z energijo, ki bo stalna naloga v celotnem dolgoročnem planskem obdobju, se bodo spremenila območja povpraševanja, tako da bodo osredotočena predvsem na ožji krog dostopnosti peš ali z javnim prevoznim sredstvom.« (Dolgoročni plan občin in mesta Ljubljane... 1986, 875).

Na koncu dolgoročni plan našteva tudi konkretna območja, za katera je bilo načrtovano urejanje s prostorskimi izvedbenimi načrti. Na območju občine Medvode je bilo predvidenih 15 prostorskih izvedbenih načrtov, od tega deset zazidalnih načrtov. Zanimivo je, da je bilo pet predvidenih zazidalnih načrtov umeščenih v okoliška naselja in ne v občinsko središče ali na njegov rob. 
Pri vrednotenju dolgoročnega plana je potrebno upoštevati njegov nastanek v socialistični družbeni ureditvi, katere konca ni predvideval. Kljub temu lahko ugotovimo, da se na načelni ravni plan večinoma ujema $\mathrm{z}$ načeli urejanja prostora, ki veljajo še danes in so omenjeni v Strategiji prostorskega razvoja Slovenije, Politiki urejanja prostora RS, Zakonu o prostorskem načrtovanju in Prostorskem redu Slovenije. Dolgoročni plan se deloma ujema $\mathrm{z}$ načelom policentričnega razvoja in usmerjanjem poselitve $\mathrm{v}$ urbana področja, popolnoma pa se ujema v zagovarjanju prenove pred novogradnjami, gradnje znotraj naselij, širitve poselitvenih območij na robu obstoječih, večanja gostote stanovanjskih območij, prepletanja rab, javnega prometa pred osebnim in varovanja pokrajin ter dediščine.

$\mathrm{Ob}$ nastanku dolgoročnega plana leta 1985 je bil koncept trajnostnega razvoja šele $\mathrm{v}$ razvoju, zato plan ne izhaja iz trajnostnega oz. vzdržnostnega prostorskega razvoja, kot današnji sistem urejanja prostora. Prav tako zaradi načeloma močno omejene vloge zasebnih interesov v socialistični družbi dolgoročni plan ne poudarja delovanja planskega sistema $\mathrm{v}$ javnem interesu. Lokacija $\mathrm{z}$ dolgoročnim planom predvidenih prostorskih izvedbenih načrtov ni popolnoma $\mathrm{v}$ skladu $\mathrm{z}$ načelnimi usmeritvami $\mathrm{v}$ tekstualnem delu plana, saj je plan predvideval gradnjo stanovanjskih naselij na kmetijskih zemljiščih $\mathrm{v}$ bližini vaških ali suburbanih naselij in ne v območju Medvod (kar pa je bilo v skladu s takratnim povpraševanjem in težnjami $v$ prostoru). $Z$ dolgoročnim planom določena območja urejanja tudi niso povsem v skladu z načeli dobrega urejanja prostora, saj je bil prostor današnje občine Medvode ob njihovem oblikovanju že prizadet zaradi dveh desetletij suburbanizacije. Tako tudi meje območij urejanja sledijo medsebojno zraščenim naseljem.

\section{PRIMERJAVA PLANSKEGA IN DEJANSKEGA STANJA}

Primerjava planskega stanja po dolgoročnem planu z dejanskim stanjem leta 2003 kaže na zelo nizko stopnjo udejanjanja njegovih načel in določil. Temeljne usmeritve prostorske razporeditve prebivalstva in delovnih mest se niso uresničile niti v kontekstu občine Medvode, niti v kontekstu območja vseh nekdanjih ljubljanskih občin. V procesu tranzicije so pretežno industrijske Medvode izgubljale delovna mesta, $v$ tem procesu pa so nekatere proizvodne površine deloma spremenile namembnost. Uresničila se je le rast prebivalstva v občini, ki pa je bila vezana na zaposlovanje v Ljubljani. Delovna migracija, relativna in absolutna, je močno narasla.

Načrtovana zasnova poselitve je bila v opazovanem obdobju delno uresničena. Naselja ob prometnem koridorju Ljubljana-Kranj so rasla nadpovprečno hitro, večina organizirane gradnje, še posebej pred letom 1990, pa je potekala v samih Medvodah. Od dveh, v organizirani gradnji zgrajenih naselij enostanovanjskih hiš, je naselje Na klancu ustrezno umeščeno na robu Medvod, v bližini ceste Ljubljana-Kranj in tudi dobro povezano z javnim prometom. Naselje Brezovec pa je umeščeno v nasprotju z dolgoročnim planom stran od predvidenega naselitvenega koridorja na predhodno nenaseljenem območju in ni povezano z javnim prometom.

Bolj problematična je individualna gradnja hiš, ki je potekala nenadzorovano na robovih obstoječih naselij in zaselkov. Slika 1 prikazuje urbanizirane površine, ki se nahajajo izven ureditvenih območij naselij. Samotne kmetije in posamezni objekti (hiše, vikendi) v prikaz 
niso vključeni. Urbanizacija je močno posegla na površine, ki ji niso bile namenjene; v kmetijska in gozdna območja se zajedajo jeziki urbaniziranih površin. V hribovitem delu občine so se območja posameznih kmetij razširila v urbanizirane otoke. Medsebojno zrasla so se nekatera naselja, ki ob sprejetju plana še niso bila zraščena. Obenem pa ureditvena območja naselij še zdaleč niso bila zapolnjena. V opazovanem obdobju ni prihajalo do izvajanja projektov notranje obnove naselij, z izjemo začetka izgradnje središča Medvod.

Moč neorganizirane stanovanjske gradnje je deloma posledica izpada organizirane stanovanjske gradnje. Od načrtovanih 891 stanovanj je bilo med letoma 1986 in 2000 zgrajenih le 160 stanovanj v večstanovanjski gradnji. Po letu 1990 se je organizirana stanovanjska gradnja ustavila, nadaljevala pa se je razpršena individualna gradnja, ki ni upoštevala usmeritev glede lokacije novogradenj, urejanja naselij in oblikovanja zgradb.

\section{Slika 1: Poselitev v občini Medvode}

Figure 1: Settlement areas in the Medvode municipality (avtor: Janez Berdavs)

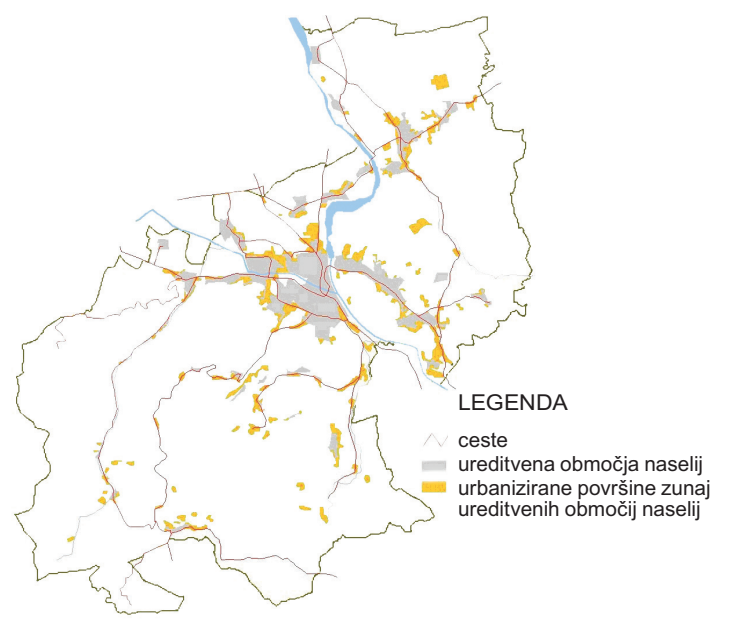

Vir: Dolgoročni plan občin in mesta Ljubljane za obdobje 1986-2000; GURS

Ravno urejanje naselij in oblikovanje zgradb sta področji, kjer planske usmeritve dosegajo najnižjo stopnjo uresničenosti in je stanje tudi ne glede na planske usmeritve popolnoma nezadovoljivo. Nekdanja podeželska naselja v občini so popolnoma izgubila prvotni značaj in so enaka suburbanim naseljem v večini ostalih delov Slovenije. Oblikovanje stanovanjskih hiš v ničemer ne sledi krajevni tipiki in tudi ne razvija novega sloga in novih oblikovanih kvalitet v naselju. Suburbana gradnja odstopa od krajevne tipike po legi, usmerjenosti, velikosti, tlorisu in gabaritih objektov, naklonih in tipih streh ter po barvah in kritinah. Stanje slabšajo pogosti prizidki in nadzidki ter pomožni objekti in občasno tudi splošna neurejenost iz javnih površin vidnih delov funkcionalnih zemljišč. Zaradi nadomeščanja starejših stanovanjskih zgradb in opuščanja kmetij izginjajo stara vaška jedra. V nasprotju z usmeritvami plana je tudi oblikovanje z zazidalnim načrtom in organizirano gradnjo zgrajenega naselja Na Klancu 
(Odlok o zazidalnem načrtu za območje urejanja ŠS 12/1-1 Na klancu 1999). Hiše so v tem naselju zgrajene večinoma iz lesa, glede na svojo površino so precej nizke (dimenzije za tip hiše P1 16,85 x 9,60 m, višina slemena 5,40 - 7,90 m), strehe pa so štirikapne. Vse to daje hišam precej 'ameriški' videz, ki deluje v tem okolju tuje.

Neustrezni sta parcelacija gradbenih parcel in ulična mreža, ki sta bili razviti spontano in postopno. Takšna parcelacija pušča precej prostih površin znotraj naselij, vendar zaradi velikosti ter oblike lahko tudi neuporabnih za zgoščevanje naselij. Dolgoročni plan v kartografskem delu določa tudi varovalne pasove cest, železnic in daljnovodov. Med objekti, ki se nahajajo znotraj varovalnih pasov cest, železnice in daljnovodov, pa je bila večina zgrajena pred začetkom obravnavanega planskega obdobja. Ulična mreža je nepovezana, sestavljena iz dolgih slepih ulic, kar je lahko nevarno v primeru različnih nesreč. Obračališč na koncu ulic ni; ulice v naseljih na neravnem terenu so lahko tudi zelo strme. Ulice so pogosto ozke in vedno brez pločnikov, tudi tiste, ki vodijo do šol. Pločnike ima le večina lokalnih cest, ki vodijo skozi naselja. Slepi konci ulic medsebojno niso povezani s peš prehodi; tako so lahko medsebojno bližnje hiše dostopne le po mnogo daljši poti. Izvozi iz dvorišč pogosto niso izvedeni na napajalno ulico, ampak neposredno na glavno cesto v naselju. V neorganizirani gradnji zgrajena stanovanjska naselja tudi nimajo parkirnih mest za obiskovalce. Urejanje cest (asfaltna prevleka) sledi gradnji naselja z zamikom.

Zelo viden element urejanja suburbanih naselij v medvoški občini, ki pa nima podlage v lokalni tipiki, so ograje. Te so postavljene neposredno na parcelno mejo in lahko zaradi višine in materialov povzročajo nepreglednost križišč in izvozov in tako zmanjšujejo prometno varnost, kar je v nasprotju z veljavnimi prostorskimi ureditvenimi pogoji. Posledica ograjevanja je tudi vizualna privatizacija prostora $\mathrm{v}$ naseljih, saj je pogled po naselju lahko omejen le na ulico in višje dele hiš. Javne površine so omejene samo na cestne površine in redke pločnike, zelenih in rekreacijskih površin ni. Zaradi razkroja starih vaških jeder v bolj suburbaniziranih naseljih ne moremo več govoriti o simbolnem središču naselja.

Naslednji netipičen prostorski element, ki je $\mathrm{v}$ nasprotju s splošnimi smernicami dolgoročnega plana o oblikovanju naselbinskega prostora, so škarpe. Te so pogoste v naseljih v Polhograjskem hribovju in naseljih, ki so nanizana vzdolž savskih teras. Glede na določila v veljavnih prostorskih ureditvenih pogojih bi moralo biti premoščanje višinskih razlik praviloma izvedeno z brežinami in zgolj izjemoma s škarpami, ki bi morale biti ozelenjene, kar je dejansko redkost. Ostali negativni posegi v prostor občine Medvode, izvedeni v planskem obdobju, so gradnja vikendov v predhodno naravnem okolju zunaj ureditvenih območij naselij, odpiranje manjših kamnolomov in zasipavanje poplavne ravnice ob Savi. Razvoj prometa je $\mathrm{v}$ planskem obdobju potekal $\mathrm{v}$ obratni smeri od načrtovane, enako se je zgodilo s prostorskim razvojem trgovine, ki se je skoncentrirala $v$ manjšem številu večjih trgovskih centrov.

Med pozitivnimi posegi v prostor lahko navedemo posege, načrtovane s prostorskimi izvedbenimi načrti, ki so, kljub pomanjkljivostim, bolj sprejemljivi, kot nenadzorovani posegi na območjih, načrtovanih s prostorskimi ureditvenimi pogoji. Na ozemlju občine so bile stalno zagotovljene površine za proizvodne dejavnosti. Poleg ureditve večine krajevnih cest je Občina ob koncu obravnavanega planskega obdobja pričela z izgradnjo kanalizacije in plinovoda $\mathrm{v}$ večjih suburbanih naseljih. 


\section{ANALIZA RAZLOGOV ZA NIZKO STOPNJO IZVEDENOSTI PLANA}

Analiza, ki je postavila v ospredje normativni vidik, kaže na dve vrsti razlogov za nizko stopnjo izvedenosti plana:

- notranji razlogi v samem sistemu planskih predpisov, veljavnih na določenem območju,

- zunanji razlogi, ki se nanašajo na izvajanje teh predpisov.

Eden od glavnih razlogov za nizko stopnjo izvedenosti je splošnost dolgoročnega plana in pomanjkanje konkretizacije usmeritev s planskimi dokumenti na nižjih ravneh. Dolgoročni plan našteva preveč ciljev in usmeritev ob opazni odsotnosti prednostnih nalog. Nekatere usmeritve so si celo nasprotujoče (npr. načrtovana ustanovitev naravnega rezervata in hkrati velikega stanovanjskega naselja v Skaručenski gmajni). Premalo pozornosti je posvečeno tudi načinom in časovnici izvajanja ciljev.

Pomembno je že omenjeno neskladje znotraj dolgoročnega plana med zasnovo poselitve in načrtovanimi prostorskimi izvedbenimi načrti, kar pa na neskladje med planskim in dejanskim stanjem ni imelo pomembnega vpliva zaradi zelo nizke stopnje izvedenosti načrtovanih prostorskih izvedbenih načrtov. Od petnajstih predvidenih prostorskih izvedbenih načrtov na ozemlju občine Medvode jih je bilo sprejetih le pet, od teh sta bila deloma izvedena le dva. Prostorski izvedbeni načrti, veljavni v opazovanem obdobju, ki niso bili predvideni z dolgoročnim planom, so večinoma skladni z usmeritvami dolgoročnega plana. Zazidalni načrt za stanovanjsko naselje Na klancu je neskladen glede oblikovanja hiš, zazidalni načrt za stanovanjsko naselje Brezovec pa glede lokacije naselja. Leta 1998 so bila s spremembami in dopolnitvami dolgoročnega plana območja urejanja naselij povečana, tako da so obsegala tudi območja novejše suburbanizacije. Plan se je torej prilagajal stanju na terenu in ne obratno.

Nizko stopnjo izvedenosti dolgoročnega plana pa gre pripisati neuspehu urejanja prostora s prostorskimi ureditvenimi pogoji, ki so sicer pokrivali veliko večino površin ureditvenih območij naselij. Večina usmeritev dolgoročnega plana ni vključena v odloke o prostorskih ureditvenih pogojih in je zaradi splošnosti ostala neuresničljiva.

Prostorski ureditveni pogoji vsebinsko ne pokrivajo nekaterih usmeritev dolgoročnega plana, za katere pa tudi ni bil izdelan ustrezen sektorski plan. V njih ni določil glede integracije urejanja naselij in načrtovanega spodbujanja javnega prometa; enako velja za usmerjanje razvoja naselij v skladu z načrtovanim razvojem trgovinske dejavnosti. Bolj problematična je nedoločnost in neoprijemljivost večine ostalih prostorskih ureditvenih pogojev in pogosto oblikovanje njihovega besedila v slogu priporočil. Poleg tega prostorski ureditveni pogoji zanikajo raznolikost naselij in prostora nasploh: kljub delitvi območij urejanja na morfološke enote, ki bi morale biti temeljna enota urejanja prostora, ne specificirajo določil po posameznih morfoloških enotah. Še več: prostorski ureditveni pogoji so za območje občine Medvode tako iz leta 1989, kot tudi tisti iz leta 1998, vsebinsko skoraj enaki za celotno območje občine, kljub dejstvu, da veljajo v vsaki planski celoti posebni prostorski ureditveni pogoji.

Nedoločnost prostorskih ureditvenih pogojev, veljavnih $\mathrm{v}$ obravnavanem obdobju $\mathrm{v}$ občini Medvode, kaže sledeči člen: »Novogradnje, nadzidave, prezidave, pomožni in začasni 
objekti ter drugi posegi v prostor morajo vzdrževati vzpostavljeno oblikovno identiteto in homogenost območja in se prilagajati okoliškim objektom in ureditvam po:

- zasnovi izrabe funkcionalnega zemljišča,

- odmikih od sosednjih objektov,

- sestavi osnovnih gradbenih mas,

- višini in gradbeni črti,

- naklonu streh in smereh slemen,

- razmerju fasad in njihovi orientaciji,

- merilih in razporeditvi fasadnih elementov, zlasti oken in vrat,

- barvi in teksturi streh in fasad,

- načinu ureditve odprtega prostora,

- načinu izvedbe ograj in drugih posegov v prostor.« (Odlok o prostorskih ureditvenih pogojih za plansko celoto Š 15 - Golo Brdo-Žlebe 1989, 924).

Prostorski ureditveni pogoji pa obenem ne pojasnijo, kaj pomeni 'vzpostavljena oblikovna identiteta in homogenost območja', saj je bila ob sprejetju predpisov v drugi polovici osemdesetih let prejšnjega stoletja po dveh desetletjih suburbanizacije prostorska identiteta že močno zabrisana. Vprašljivo je npr. tudi predpisovanje gradbene črte v naseljih, ki so že tradicionalno gručasta oz. sestavljena iz samotnih kmetij in zaselkov. Prostorski ureditveni pogoji tako ne vsebujejo nobenih konkretnih navodil glede oblikovanja zgradb in njihove umestitve na parceli. Prav tako ne vsebujejo konkretnih določil o parcelaciji, varstvu okolja, krajinskih prvinah (ki so prav tako močno preoblikovane s suburbanizacijo) in ne preprečujejo nenadzarovane gradnje vikendov ter odpiranja nelegalnih kamnolomov v Polhograjskem hribovju ter zasipavanja poplavne ravnice ob Savi. Prostorski ureditveni pogoji, veljavni med 1989 in 1998, tudi niso vsebovali določil v zvezi s prometno mrežo v naseljih.

Dejansko stanje $\mathrm{v}$ prostoru je tako kaotično tudi zaradi kršenja tistih načel, ki jih prostorski ureditveni pogoji določajo dovolj nedvoumno. Tako so zelo pogosto kršena določila o upoštevanju naravnega reliefa pri urejanju stavbnih parcel (zelo pogosto je premagovanje neravnin s škarpami), o varovanju značilnih pogledov, o varovalnih pasovih cest in daljnovodov in o priključitvi vseh novogradenj na komunalno infrastrukturo. Večina naselij v občini Medvode nima urejenega kanalizacijskega omrežja oz. je ta še v izgradnji, ureditev notranjih dostopnih cest $\mathrm{v}$ naseljih pa pogosto $\mathrm{z}$ zamikom sledi spontani gradnji stanovanjskih hiš. Redkejše, a resnejše so kršitve določil o dovoljenih vrstah posegov v ureditvenih območjih naselij, saj so bile npr. v stanovanjskih območjih zgrajene proizvodne hale ali pa urejena velika parkirišča za tovornjake. Po vključitvi določil o urejanju internih prometnic v stanovanjskih naselij v prostorske ureditvene pogoje po letu 1998 se stanje na tem področju ni izboljšalo, slepe ulice so še vedno brez obračališč, mnogi priključki so zaradi visokih ograj nepregledni, kar je v nasprotju s predpisanimi pogoji.

\section{SKLEP}

V prispevku so nakazani glavni razlogi za nizko stopnjo uresničenosti prostorskega plana občine Medvode, izdelanega leta 1986 in veljavnega do danes. Prostorske sestavine 
dolgoročnega in družbenega plana so presplošne, imajo preveč ciljev brez vzpostavljene notranje hierarhije, zato takšen plan ni mogel biti podlaga koncentraciji omejenih sredstev in aktivnosti na nekaj prednostnih področij. Dolgoročni plan je nastal v socialističnemu družbenemu redu in mu je bil izvorno tudi prilagojen, kar vsaj deloma razlaga neuresničenost nekaterih ciljev.

Še pomembneje je, da so bila planska določila v premajhni meri konkretizirana in operacionalizirana $\mathrm{v}$ podrejenih prostorskih dokumentih. Prostorskih izvedbenih načrtov je bilo sprejetih premalo glede na razvojne potrebe priljubljanskega suburbanega prostora, prostorski ureditveni pogoji, s katerimi naj bi se urejala večina tega prostora, pa so, podobno kot dolgoročni plan, preohlapni oz. vrsto potrebnih določil sploh izpuščajo. Na tem mestu lahko kot problemsko točko prejšnjega planskega sistema izpostavimo prevelik razkorak med togostjo prostorskih izvedbenih načrtov in ohlapnostjo prostorskih ureditvenih pogojev.

Podobno ugotavlja Breda Ogorelec (1991), ki neupoštevanje prostorske raznolikosti v prostorskih ureditvenih pogojih ugotavlja na ravni celotne Slovenije in to pripisuje pomanjkljivemu strokovnemu delu izdelovalcev predpisov. Ugotavlja tudi, da je javni, skupni interes premalo poudarjen. Urbanistični predpisi bi morali podrobneje regulirati tiste elemente, ki vplivajo na javno podobo kraja; torej elemente, ki vplivajo na podobo naselja kot celote (veduta) in na podobo, ki se kaže ob pogledih z javnih površin.

Končno pa je za nizko stopnjo izvedenosti plana kriva tudi nizka stopnja uveljavljanja s prostorskimi ureditvenimi pogoji in ostalimi akti konkretiziranih določil v prostorski politiki 'na terenu'. K temu so svoje prispevale tudi velike spremembe družbenega in pravnega sistema, ki se jim je planski sistem le prilagajal, in reforma lokalne samouprave, ki je oslabila planske in nadzorne službe na lokalni ravni.

Primer iz tega članka tudi kaže na planski sistem, ki ga ni mogoče označiti z vsestranskim (comprehensive), postopnim (increment) planiranjem ali s katero drugo teorijo prostorskega planiranja. Kaže na planski sistem, ki je bil slabo oblikovan in neuspešen v izvajanju zaradi pomanjkljive politične volje na državni in lokalni ravni ter nizke ravni zavesti o prostoru kot skupnem dobrem med prebivalstvom in lastniki nepremičnin.

\section{Viri in literatura}

Dalla Valle, S. 2001: Strokovne podlage za dolgoročni in srednjeročni plan Občine Škofja Loka ter za Urbanistično zasnovo mesta Škofja Loka. Urbi, Urbanistični inštitut Republike Slovenije, 512 str. Ljubljana.

Dolgoročni plan občin in mesta Ljubljane za obdobje 1986-2000. Uradni list SRS 11/86. Ljubljana 1986.

Družbeni plan občine Ljubljana-Šiška za obdobje 1986-1990. Uradni list SRS 45/86. Ljubljana 1986.

Geografski atlas Slovenije. DZS. Ljubljana 1998.

Odlok o prostorskih ureditvenih pogojih za plansko celoto Š 9 - Medvode. Uradni list SRS 19/89. Ljubljana 1989.

Odlok o prostorskih ureditvenih pogojih za plansko celoto Š 10 - Pirniče. Uradni list SRS 2/89. Ljubljana 1989. 
Odlok o prostorskih ureditvenih pogojih za plansko celoto Š 11 - Skaručna. Uradni list RS 55/92. Ljubljana 1992.

Odlok o prostorskih ureditvenih pogojih za plansko celoto Š 12 - Zbilje. Uradni list SRS 39/88. Ljubljana 1988.

Odlok o prostorskih ureditvenih pogojih za plansko celoto Š 13 - Smlednik. Uradni list RS 55/92. Ljubljana 1992.

Odlok o prostorskih ureditvenih pogojih za plansko celoto Š 15 - Golo Brdo-Žlebe. Uradni list SRS 16/89. Ljubljana 1989.

Odlok o prostorskih ureditvenih pogojih za plansko celoto Š 16 - Trnovec-Topol. Uradni list SRS 16/89. Ljubljana 1989.

Odlok o zazidalnem načrtu za območje urejanja ŠS 12/1-1 Na klancu. Uradni list RS 49/99. Ljubljana 1999.

Ogorelec, B. 1991: Urbanistični predpisi - prispevki k študiju normativnega urbanizma. Ljubljana, Urbanistični inštitut Republike Slovenije, 105 str. Ljubljana.

Politika urejanja prostora Republike Slovenije. Ministrstvo za okolje, prostor in energijo. Ljubljana 2002. Medmrežje: http://www.mop.gov.si/fileadmin/mop.gov.si/pageuploads/ publikacije/drugo/politika-upro.pdf (18. 3. 2008)

SI-STAT podatkovni portal. Medmrežje: http://www.stat.si/pxweb/Dialog/statfile2.asp (11. 4. 2008)

Strategija prostorskega razvoja Slovenije. Ministrstvo za okolje, prostor in energijo. Ljublja-na 2004. Medmrežje: http://www.mop.gov.si/fileadmin/mop.gov.si/pageuploads/publikacije/drugo/sprs_slo.pdf (18.3.2008)

Uredba o prostorskem redu Slovenije. Uradni list RS 122/04. Ljubljana 2004.

Zakon o prostorskem načrtovanju. Uradni list RS 33/07. Ljubljana 2007.

Zakon o urejanju naselij in drugih posegov v prostor. Uradni list SRS 18/84. Ljubljana 1984. Medmrežje: http://www.mop.gov.si/fileadmin/mop.gov.si/pageuploads/zakonodaja/prostor/urejanje/urejanje_prostora.pdf (2. 5. 2008)

Zakon o urejanju prostora. Uradni list SRS 18/84, Uradni list SRS 15/89 in Uradni list RS 71/93. Medmrežje: http:/www.mop.gov.si/fileadmin/mop.gov.si/pageuploads/zakonodaja/prostor/urejanje/urejanje_prostora.pdf (2. 5. 2008)

\section{A COMPARISON OF PLANNED AND ACTUAL SITUATION IN SPACE OF THE MEDVODE MUNICIPALITY}

\section{Summary}

In the year 1984 Spatial planning act was adopted in Slovenia. This act was the basis for new planning system in Slovenia, which was fully valid until adoption of new planning act in 2003. However, most of earlier spatial regulation remained in power until adoption of most recent planning legislation in 2007. On basis of 1984 legislation, a 15-year spatial plan for the municipality of Ljubljana-Šiška, part of which was present-day Medvode municipality, was enacted. This article presents the rate of plan implementation during the period 1986-2003. 
According to the plan, it should have been realized by the year 2000; 2003 is the year of adoption of new spatial act.

The aims of the paper are the evaluation of the 1986 municipal plan from the point of view of present-day planning principles and comparative analysis of the municipality's spatial plan and actual state in municipal territory. The actual situation has been determined mostly with help of orthophotographs and fieldwork. Analysis of the reasons for low level of plan implementation has been conducted with interviews with head of municipality's planning department and review of regulations in legislation. Special attention has been given to relations between various levels of planning legislation.

The Medvode municipality was re-created in 1994 from former municipality of Ljubljana-Ššška. It is one of suburban municipalities that encircle the city of Ljubljana. It has 14.793 inhabitants on area of $78 \mathrm{sq}$. kms. The population increase in period 1961-2007 was $88 \%$. While municipality's center Medvode is industrialized and has urban structure, all other settlements are suburban and without significant employment opportunities.

Municipal spatial plan, valid for the period of 15 years, in its role comparable to German Flächennutzungsplan, was part of hierarchy of municipal planning regulation. It envisaged implementation through three five-year mid-term municipal plans and through implementing acts. These acts were subdivided into implementing plans that regulate specific developments (comparable with German Bebauungsplan), and into spatial regulation terms, which are suitable for areas with minor development.

Municipal spatial plan, although created in 1986, is generally still in line with principles of spatial planning, as defined in contemporary spatial planning documents valid in Slovenia and the EU. It is, however, too general, it includes very wide list of objectives without stating priorities or hierarchy of objectives. Moreover, some of its objectives are even contradictory.

Comparative analysis has shown wide discrepancy between planned and actual state of space in the Medvode municipality. The discrepancy is widest in building design, urbanization outside areas zoned for development, land allotment and design of traffic network inside settlements.

We have identified two types of reasons for such a situation: those within the planning legislation and those connected to performance of planning system. The article reveals how the reasons within planning system have contributed to the undesired state of spatial development in the municipality. Most important reason is, next to mainly general nature of municipal spatial plan, the fact that the planning directions and objectives, as defined in municipal spatial plan, have not been concretized with planning regulations, subordinated in planning regulation hierarchy.

The number of adopted and realized implementing plans was far too low on one hand. Spatial regulation terms are, on the other hand, too general for quickly developing suburban municipality. The main deficiencies of spatial regulation terms are the disregard of spatial variability (majority of the content is the same for all parts of settlements and all settlements in the municipality) and vague nature of provisions, which are written in narrative instead of normative style and can be ambiguous or, sometimes, meaningless. Moreover, the violations of unambiguous provisions are common. 